\title{
THE IMPACT OF SUBSIDIES ON PRODUCTION INNOVATION AND SUSTAINABLE GROWTH
}

\author{
Sabina Žampa, Štefan Bojnec \\ University of Primorska, Faculty of Management, Slovenia \\ Corresponding author: \\ Sabina Žampa \\ University of Primorska \\ Faculty of Management \\ Cankarjeva 5, SI-6000 Koper, Slovenia \\ phone: (+386) 31865278 \\ e-mail: sabina.zampa@fm-kp.si
}

Received: 5 July 2017

Accepted: 9 November 2017

\begin{abstract}
This paper investigates correlation between subsidies to invest in development projects, innovation, financial performance and sustainable growth. The focus of the study is on subsidies for co-financing purchases of new technological equipment aimed at promoting innovation and production of new products. Subsidies are distributed based on the prepared European Union (EU) and national programs for the purposes of faster economic growth in accordance with the policies and guidelines of the EU. The paper employs a combination of enterprises' accounting data, data on subsidies and unique in-depth data obtained through a survey at the enterprise level. The results revealed a positive impact of subsidies on financial indicators, and only limited effect on innovation. While analyzing sustainable growth, we have established that the enterprises that received subsidies had a higher growth of financial indicators.
\end{abstract}

KEYWORDS

subsidies, innovation, sustainable growth, research and development, financial efficiency, small and medium enterprises.

\section{Introduction}

One of the main socio-economic objectives of the European Union (EU) is to promote balanced and sustainable economic and social progress, in particular through the creation of an area without internal frontiers, through strengthening economic and social cohesion, and through the establishment of an economic and monetary union [1]. The idea of public aid programs for strengthening local economic performance is widely recognized and used by many national or local governments [2]. The European Commission (EC) provides direct funding in the form of subsidies to projects and organizations that support European interests and are involved in implementing EU programs and policies [3].

In accordance with the EU rules, Slovenia had to compile programming documents for cohesion policies for the 2007-2013 period. The National Strate- gic Reference Framework (NSRF) defines prosperity as a global goal, and emphasizes the promotion of economic growth and job creation (two key goals of the Lisbon Strategy), and cohesive regional development.

The ability to build sustainable development based on growth of small and medium sized enterprises (SMEs) and innovation potentials is thus crucial for the future prosperity of the EU. The importance of SMEs in society can be even greater, as they provide employment opportunities and are an essential factor in creating prosperity for local and regional communities. Accordingly, the EU put the needs for growth of SMEs firmly at the centre of the Lisbon Strategy for Growth and Jobs [4]. SMEs form the backbone of the EU-28 economy [5]. Given the significant scale of small business in nearly every economy, their aggregate achievements have a major effect worldwide [6]. 
SMEs perform fundamental role in various stages of economic development $[7,8]$. SMEs are a main driver of economic growth, innovation and technological progress $[9,10]$.

A major objective of governmental research and development (R\&D) subsidy programs is to reduce the constraints on the financing of innovation [11]. The analysis of the effects of public R\&D subsidies is a typical policy evaluation problem. The question of interest is what the effect of government R\&D subsidies on funded firm is [12].

The growing enterprises should not neglect the importance of sustainability from the economic, social or environmental aspect. Whilst enterprises recognize their considerable role and responsibilities in sustainability $[13,14], 90 \%$ of worldwide businesses are categorized as SMEs and generate approximately $50-60 \%$ of employment opportunities [15].

Subsidies are one of the possibilities for strengthening the economic growth and can be obtained by enterprises with appropriate projects through tenders. Subsequently, the purpose of this study was to focus on the impact of subsidies on financial performance, development and innovation in SMEs and sustainable growth of enterprises.

\section{Theoretical background}

\section{Subsidies}

Funds from the EU budget are spent in areas where the financial support generates the strongest effect [16]. The EC provides direct funding as nonrepayable or repayable aid to projects and organizations that support European interests and are involved in implementing EU programs and policies $[3,17]$.
In the 2004-2006 period, EUR 239 million of EU funds were available to Slovenia [1, 18], in the 20072013 period the available funds amounted to EUR 4.1 billion [19], and in the 2014-2020 period around EUR 3.255 billion are available to Slovenia from the European Structural Funds - the European Regional Development Fund (ERDF), European Social Fund, and Cohesion Fund.

In the 2007-2013 period, enterprises could obtain subsidies for additional investments in technological equipment, R\&D, business premises, business processes and other intangible investments. Subsidies could be acquired at the national level (decentralized programs), and the EU level (centralized programs).

Enterprises receive subsidies based on the appropriate applications with which they apply for specific public tenders. Public tenders are implementation operations based on national and European programs with specific objectives and results. A region will achieve the desired progress in the area of sustainable growth only with the appropriate allocation of subsidies from public tenders. The EU devotes funds for the economic growth of a region with financial resources within an individual multiannual financial framework.

As can be seen from Table 1, the EU devotes $45 \%$ of its budget for measures of the "sustainable growth".

In planning of investment activities, $R \& D$ is an important process of successful enterprise management. Coordinating the activities with time schedules of institutions granting subsidies at the national or EU level, and their different areas of work it is important for an enterprise's future growth. Obtaining and implementing subsidies can have a significant impact on the enterprise's development and growth. SMEs are especially sensitive in this area.

Table 1

EU budget 2007-2013.

\begin{tabular}{l|c|c|}
\hline \multicolumn{1}{c|}{ Commitment appropriations } & Total (billion EUR) 2007-2013 & $\%$ \\
\hline 1. Sustainable Growth & 439.115 & 45.00 \\
\hline 1a. Competitiveness for Growth and Employment & 90.25 & 9.25 \\
\hline 1b. Cohesion for Growth and Employment & 348.865 & 35.75 \\
\hline 2. Preservation and Management of Natural Resources & 412.611 & 42.29 \\
\hline 3. Citizenship, freedom, security and justice & 12.247 & 1.26 \\
\hline 4. EU as a global player & 55.935 & 5.73 \\
\hline 5. Administration & 54.932 & 5.63 \\
\hline 6. Compensations & 0.937 & 0.10 \\
\hline Total commitment appropriations & 975.777 & 100.00 \\
\hline
\end{tabular}

Source: European Commission (2017) [20]. 


\section{Subsidies - Product 4}

One of the biggest public tenders conducted by Slovenian Enterprise Fund (SEF) was Product 4 (P4). Between 2006 and 2009, SEF granted a total of EUR 315,972,379 in investments through the P4 tender, granting subsidies in the amount of EUR $135,316,329$. The subject of the public tender $\mathrm{P} 4$ was co-financing (direct subsidies) of the purchase of new technological equipment that represents the initial investment. Initial investments are investments in tangible and intangible assets related to the establishment of a new business, expansion of an existing business, expansion of the enterprise's activities to new, additional products or a fundamental change in the overall production process of an existing enterprise. The purpose of the $\mathrm{P} 4$ public tender was to promote and encourage initial investments, which should be reflected in greater competitiveness of enterprises, measured by increased growth and productivity, a more competitive performance with higher value added per employee.

The eligible costs included: material investments (purchase of new machinery and equipment) and immaterial investments (purchase of software). The investment had to represent a meaningful technological whole and had to be associated with new products/services.

The enterprises received subsidies if their projects met the criteria of the sets "technology" and "innovation". The projects by the enterprises that introduced new technological lines, the associated plants or systems representing technological and informational solutions in connection with the technological process were entitled to a subsidy. Technological solutions that enable the implementation of a new product/service as a result of an enterprise's own development are being introduced. Our analysis focuses on the enterprises that received $\mathrm{P} 4$ subsidies.

\section{Subsidies for research, development and innovation}

Subsidies are primarily granted to enterprises for research, development and innovation (RDI). Studies on the impact of subsidies on $R \& D$ have been conducted for example in Germany, Ireland, Finland, Slovakia, the Czech Republic and Spain. Government subsidies can boost $\mathrm{R} \& \mathrm{D}$ activities that would not have been conducted without this funding [21]. Usually this is because such funding is cheaper than any other capital. There are also claims that obtaining subsidies is positively correlated with variables that reflect research experience [22]. According to [23], enterprises that received subsidies have stronger $\mathrm{R} \& \mathrm{D}$ on average. Enterprises that received subsidies increased investment in R\&D by around $4 \%$. Enterprises in the Czech Republic and Slovakia would carry out more than one third of the projects even without receiving the subsidies [2]. Agricultural subsidies can have negative impacts on technical efficiency of farms [24].

Manufacturing enterprises in Finland that received lower subsidies increased the share of own funding for $R \& D$, while excessively high subsidies resulted in a decrease in own funding that enterprises were willing to allocate for R\&D [25]. Sufficiently high subsidies encouraged enterprises to increase export and operate in foreign markets more efficiently [26]. However, there is no evidence that subsidies boosted export in enterprises that had not exported before. A positive correlation between exports and investments in $R \& D$ in exporting countries was found, while the regression coefficient for $R \& D$ variables in importing countries was mixed [27, 28].

Subsidies provide a significant share of $R \& D$ funding in Finland. The number of filed patents would drop without subsidies, and data also shows that enterprises that had not received subsidies for their R\&D would be much more efficient if they had received them demonstrated that subsidies reduced obstacles in financing technological equipment in Finland [11, 29].

A survey conducted in 2000 Spanish enterprises showed that subsidies for R\&D partially boosted $R \& D$, and that some enterprises would not be conducting R\&D without them. However, the majority of subsidies are granted to enterprises that would conduct $\mathrm{R} \& \mathrm{D}$ in a more or less same extent even without them [22]. Study conducted in Spanish manufacturing enterprises between 1998 and 2009 showed that subsidies may have lasting incentive effects in $9 \%$ of all Spanish manufacturing enterprises [30]. Smaller enterprises (with less than 200 employees) require higher subsidies.

In Germany, there is concluded that market uncertainty can result in a drop in $R \& D$ investment, while subsidies for RDI lead to higher investment in $R \& D$ [31]. R\&D subsidies can mitigate the effects of market uncertainty.

\section{Sustainable growth}

It is important how organizations manage their growth to make it sustainable and not fall into the trap of excessive growth. Organizations that operate in a sustainable manner are the driving force of market economy [32]. Sustainable growth means building a sustainable and competitive economy that uses 
resources efficiently and strengthens the enterprises' competitive advantages, especially in manufacturing and among SMEs, as well as raising consumer awareness about the benefits of using resources economically [3]. Sustainable growth means that an organization's revenue as well as profit increase over a prolonged period of time, while the organization generates a total return for investors that exceed the total cost of equity or capital [32]. Growth can be deemed sustainable when an enterprise's revenue and profit increase over a prolonged period of time, while the total return for investors exceeds the total cost of equity [33].

According to data from the [19], Slovenia undertook to pursue three EU growth priorities (sustainable, smart and inclusive growth) in a number of documents and with the process of economic management at the EU level (National Reform Program, Stability and Growth Pact, Fiscal Compact), and primarily the Europe 2020 Strategy. Sustainable development will be the main guiding principle for the Slovenian smart specialization strategies, S4 [34] in drawing up all programs for the absorption of EU funds. Smart specialization strategy is an alternative approach to setting countries' R\&D policies, aimed at promoting efficient and successful investments in areas that generate the highest value added and contributes to achieving sustainable growth and development goals the most [19]. German enterprises from different industries could successfully compete with low-cost competitors from around the world owing to their efficient innovation management [35]. In addition, there is study [35], which also found strong correlation between efficient innovation management and sustainable and profitable growth.

\section{Measuring business performance}

Measuring business performance of enterprises is a special challenge. Traditional systems of measuring enterprises' performance have several weaknesses, since they have focused primarily on business performance represented through financial data and calculations. There is the difference between an enterprise's financial and business performance and its effectiveness [36]. Financial performance is a subset of business performance, while business performance is a subset of effectiveness. It can be defined high performance enterprises that achieve financial and nonfinancial results that are better than those of other enterprises in their industry over a period of time of at least five to ten years [37]. The following enterprises' financial results were compared: revenue growth, profitability, return on assets, return on equity, return on investment, return on sales, and total share- holder return. Empirical evidence indicates the overwhelming importance of strategic planning for SMEs' business performance [25]. Subsidies that were obtained by enterprises in Sweden between 1987 and 1993 affected the growth, but had little impact on productivity [38]. According to [39], subsidies lead to a short-term increase in productivity, while their impact on enterprises' long-term performance is small or negligible. In addition, according to [40] not any of the subsidies types have statistically significant positive short-term or longer term impacts on the firm's labor productivity. There were attempt to find positive correlation between subsidies and effectiveness measured by profitability, financial leverage and growth, for Greek enterprises in the food and beverage industry, which received subsidies between 1982 and 1996. However, the study [41] concluded that subsidies affected only the growth of these enterprises, but not other performance measures.

\section{Hypotheses development}

We examined the correlation between financial indicators and innovation in enterprises that received subsidies in the P4 public tender. We measured two groups of effects, namely financial and indirect other effects.

The first group of effects can be measured by monitoring financial indicators published in publicly available databases such as business registry [42]. In this group we examined the effect that subsidies have on the following financial indicators: revenue, profit, increase in the number of employees and value added per employee. We monitored the second group of effects through correlation between financial indicators and innovation in enterprises. This group of effects was measured using data obtained with a questionnaire. We used Cronbach's alpha to measure the reliability of the questionnaire. We applied the principal component method to map separate variables to a determined number of new variables i.e. principal components. Principal components are expressed as a linear combination of basic variables and preserve their total variability. Principal components are ranked in decreasing order of variance [43]. This was followed by a multiple regression analysis.

Sustainable growth was measured by monitoring financing indicators: revenue, profit, number of employees, value added per employee, assets, net income, capital, operating revenues to operating expenses. With the statements pertaining to the field of sustainable development, we have also compared the sustainable growth of the enterprises that received subsidies with the ones that did not receive them. 
Three hypotheses $(\mathrm{H})$ were tested in the study: H1: Subsidies have a positive effect on the performance of enterprises measured with financial indicators.

Enterprises financial performance was measured using four indicators: net operating revenue, net profit, number of employees, and value added per employee. In the analysis, we averaged the increase in the values of financial indicators during the 20062012 period. A comparison was made whether these financial indicators of enterprises that had received subsidies were better than those of the enterprises that did not receive.

$\mathrm{H} 2$ : Effects of subsidies from the $\mathrm{P} 4$ public tender are positively correlated to innovation, which in turn is reflected in enterprise performance.

The major part of EU co-financing programs is focused on R\&D. In the 2007-2013 period, $24.8 \%$ or EUR 85.399 billion of all funds available were earmarked for innovation. In this period, EUR 4.101 billion were available to Slovenia, EUR 1.168 billion or $28.5 \%$ of which were earmarked for innovation. $23.8 \%$ of these funds were spent on RDI, $0.8 \%$ on entrepreneurship, $2.1 \%$ on innovative information and communication technology (ICT), and $1.9 \%$ on human resources [44]. According to EC's data [45], Slovenia could obtain funds from the EU budget through two important instruments: Structural Funds and the 7th Framework Program for Research (FP7). Under the 2007-2013 financial perspective, Slovenia could distribute EUR 4,101 million from Structural Funds, around EUR 1,013 million of which was associated with RDI. Subsidies from FP7 were obtained by 849 applicants, who received EUR 152 million in total. Around $15.62 \%$ of applicants were successful in obtaining the funds, which is below the EU average, which stands at $19.62 \%$.

Government of the Republic of Slovenia [18] sets a goal of improving innovation performance measured with the aggregated indicator Innovation Union Scoreboard, and raising the innovation index to the level of six top innovation leaders (Luxembourg, the Netherlands, Belgium, the United Kingdom, Ireland, and Austria), i.e. from the current 0.51 to 0.62 by 2020 .

Our study will examine whether subsidies actually resulted in enterprises' better business performance by looking for correlation between separate innovation components and subsidies. Data source about subsidies is public and was obtained from public business registry databases [43]. We collected data about innovation with a questionnaire.
H3: Enterprises that obtained subsidies achieve sustainable growth.

In the EU documents for the 2014-2020 period, sustainable development is presented as one of the key factors for EU's economic growth. The ERDF contributes to the financing of support which aims to reinforce economic, social and territorial cohesion by redressing the main regional imbalances in the EU through the sustainable development and structural adjustment of regional economies, including the conversion of declining industrial regions and regions whose development is lagging behind [46]. As stated in NSRF [47], the EU would in the medium term between 2007 and 2013 channel these cohesion funds primarily into purposes supporting sustainable economic growth, economic competition and job creation, as determined in the renewed Lisbon Strategy. We examined sustainable growth of enterprises that obtained subsidies through the P4 tender.

\section{Research methodology}

\section{Methods and data}

The relationship between financial indicators and innovation in enterprises that received grants from the P4 public tender was examined using statistical methods. Two types of effects were measured. First, financial effects were measured using financial indicators obtained through publicly available database from business registry [43]. It was examined the impact of subsidies from the P4 public tender on enterprises' financial indicators. The following financial indicators were used: revenue, profit, growth in employment, and value added per employee.

Second, the relationship between financial indicators and innovation in enterprises was examined. This group of effects was measured using data obtained with the survey questionnaire. The Cronbach's alpha was used to measure reliability of the questionnaire. This was followed by a multiple regression analysis in which the correlation between the dependent and independent variables was determined.

Third, sustainable growth of enterprises was measured using the financial indicators: revenue, profit, number of employees, value added per employee, assets, net income, capital, and operating revenues to operating expenses. We have identified the differences in responses to the statements from the field of sustainable development as well. The following aspects of sustainable growth were defined: social, economic, and ecological. 
Management and Production Engineering Review

\section{Sample and units}

For testing $\mathrm{H} 1$ and $\mathrm{H} 2$ the sample consists of SMEs that received subsidies in the $\mathrm{P} 4$ public tender. There were 918 successful applications filed by SMEs in the 2006-2009 period. The questionnaire was sent to 665 SMEs and 118 responded, representing $17.3 \%$ of the success rate. They represent $14.9 \%$ of all SMEs that were successful in the $\mathrm{P} 4$ public tender. According to their size, $44.1 \%$ was micro, $37.3 \%$ small and $18.6 \%$ medium sized enterprises.

Table 2

Age of SMEs in the sample for testing H3.

\begin{tabular}{l|c|c}
\hline \multicolumn{1}{c|}{ Age } & Number & Percent \\
\hline More than 2 to 5 years & 7 & 5.9 \\
\hline More than 5 do 10 years & 20 & 16.9 \\
\hline More than 10 do 15 years & 15 & 12.7 \\
\hline More than 15 do 20 years & 24 & 20.3 \\
\hline More than 20 do 30 years & 33 & 28.0 \\
\hline More than 30 years & 19 & 16.1 \\
\hline Total & 118 & 100.0 \\
\hline
\end{tabular}

Testing the $\mathrm{H} 3$ set includes enterprises that were established before 2000 and had at least 5 employees at the end of 2014. There were 6,190 such enterprises.

Sustainable growth was analyzed with the financial indicators for the 2000-2014 period and a survey questionnaire answered by 396 enterprises, 133 of which received subsidies. The sample was represented by $37.88 \%$ micro, $44.49 \%$ small, $13.89 \%$ mediumsized, and $4.04 \%$ large enterprises. $3.03 \%$ of the enterprises were up to 15 years old, $92.17 \%$ between 16 and 30 years old, and $4.8 \%$ more than 30 years old.

\section{Results}

\section{The financial effects: testing the H1 set}

As part of testing the $\mathrm{H} 1$ set, a financial analysis of SMEs that were successful in the $\mathrm{P} 4$ public tender was conducted. The financial effects were measured with four financial indicators: total revenue, net profit, average number of employees, and value added per employee (Table 3).

For each of the years 2006-2009, the average increase in the four financial indicators was calculated for SMEs that received subsidies in the $\mathrm{P} 4$ public tender. In addition, for each of the years 2006-2009, the average increase in the four financial indicators was calculated for SMEs that responded to the questionnaire. Then the number of positive, negative and neutral financial effects was calculated for the four indicators. Total revenue, net profit and value added per employee for the period 2006-2009 were deflated by the consumer price index, which was obtained from the Statistical Office of the Republic of Slovenia.

Table 3

The results of testing the $\mathrm{H} 1$ set.

\begin{tabular}{l|c|c|c|c|c}
\hline & \multicolumn{5}{|c}{ Average increase/decrease (in \%) } \\
\hline Year & 2006 & 2007 & 2008 & 2009 & Average \\
\hline Total revenue & 14.43 & -4.55 & 9.47 & 12.03 & 7.84 \\
\hline Net profit & 21.86 & -111.38 & 2.67 & 36.61 & -12.56 \\
\hline $\begin{array}{l}\text { Average } \\
\text { number } \\
\text { of } \\
\text { employees }\end{array}$ & 16.06 & 6.54 & 27.82 & 5.27 & 13.92 \\
\hline $\begin{array}{l}\text { Value added } \\
\text { per employee }\end{array}$ & 7.55 & 45.62 & 3.11 & 1.89 & 14.54 \\
\hline
\end{tabular}

We calculated both, the average increase of financial indicators for SMEs that were successful in the $\mathrm{P} 4$, and the average increase of financial indicators for SMEs that responded to the questionnaire. Total revenue, average number of employees and value added per employee demonstrated the positive impact of $\mathrm{P} 4$, while net profit was negative, especially in 2007.

For all SMEs that were successful in the P4 public tender, we measured 4 financial indicators, using a descriptive value: Positive, Negative, and Neutral. The measured financial indicators were classified as follows: 1442 were positive, 1208 negative and 11 neutral. This means that SMEs achieved an increase in financial indicators, and improved their financial performance.

\section{Innovation and the results of regression analysis: testing the $\mathrm{H} 2$ set}

The purpose of testing the $\mathrm{H} 2$ set is to determine the impact of innovation on SMS's performance. The analysis is based on primary data obtained from the questionnaire. The H2 set argues that the effects of subsidies from the $\mathrm{P} 4$ public tender correlate positively with innovation in the SME, which determines economic performance positively. Therefore, in the regression framework, the dependent variable is economic performance measured using value added per employee. The independent variables are the four principal components of innovation in SMEs: innovation incentives, innovation procedures and standards, innovation as the prerequisite, and ways to innovate. The tested multiple regression equation is:

$$
\begin{gathered}
\text { VAP }=\mathrm{a}+\mathrm{b} 1^{*} \text { INOI }+\mathrm{b} 2^{*} \text { INOP }+\mathrm{b} 3^{*} \text { INOS } \\
+\mathrm{b} 4^{*} \text { INOIN }+\varepsilon,
\end{gathered}
$$

where VAP - value added per employee, a - regression constant, b1, b2, b3 and b4 - regression coefficients, INOI - innovation and the way to innovate, 
INOP - innovation as a prerequisite, INOS - innovation as innovation procedures and standards, INOIN - innovation as innovation incentives, and $\varepsilon$ - error term.

The regression coefficient for the innovation incentives is negative and insignificant (Sig. 0.538) (Table 4). The regression coefficient for the innovation procedures and standards is positive and insignificant (Sig. 0.897). The regression coefficient for innovation as a prerequisite is positive and significant at the $6 \%$ significance rate (Sig. 0.056). The regression coefficient for ways to innovate is positive and significant at the $8 \%$ significance rate (Sig. 0.077).

These results suggest that value added per employee is significantly positively associated with the principal component Innovation as a prerequisite and to a lesser extent with the principal component Innovation and the way to innovate, but not with two other components.

\section{The sustainable growth: testing the H3 set}

To test the H3 set, we analyzed the growth of financial indicators: revenue, profit, number of employees, value added per employee, assets, net income, capital, and operating revenues to operating expenses. The growth of the financial indicators is prepared for the period of 7 years prior to the implementation of the financial perspective for the 20002007 period, and for the period of implementing the financial perspective for the 2008-2014 period. The financial perspective officially began in 2007 , but the enterprises could not start with their projects until 2008 due to delays in publishing public tenders. The time periods are thus set to these two intervals.

As shown in Table 5, as far as the growth of the indicators "assets", "revenue", "net income", "OROE" and "VPE" are concerned, thes en-

Table 4

The results of testing $\mathrm{H} 2$ set.

\begin{tabular}{|c|c|c|c|c|c|}
\hline \multirow{2}{*}{ Predictors } & \multicolumn{2}{|c|}{ Unstandardized coefficients } & \multirow{2}{*}{$\frac{\text { Standardized coefficients }}{\text { Beta }}$} & \multirow{2}{*}{$\mathrm{t}$} & \multirow{2}{*}{ Sig. } \\
\hline & $\mathrm{B}$ & Std. Error & & & \\
\hline Constant & 3.585 & 0.153 & & 23.419 & 0.000 \\
\hline Innovation - innovation incentives & -0.095 & 0.154 & -0.056 & -0.618 & 0.538 \\
\hline Innovation - innovation procedures and standards & 0.020 & 0.154 & 0.012 & 0.130 & 0.897 \\
\hline Innovation - innovation as a prerequisite & 0.297 & 0.154 & 0.176 & 1.932 & 0.056 \\
\hline Innovation - ways to innovate & 0.274 & 0.154 & 0.163 & 1.783 & 0.077 \\
\hline
\end{tabular}

${ }^{a}$ Dependent variable: Value added per employee (VAP).

Table 5

The growth of financial indicators over the years (in \%).

\begin{tabular}{|c|c|c|c|}
\hline Financial indicators & Average 2000-2014 & Average $2000-2007$ & Average 2008-2014 \\
\hline \multicolumn{4}{|l|}{ Assets } \\
\hline Enterprises - RS & 1.384 & 1.755 & 1.078 \\
\hline Enterprises - NRS & 1.392 & 1.778 & 1.053 \\
\hline \multicolumn{4}{|l|}{ Revenue } \\
\hline Enterprises - RS & 1.379 & 1.734 & 1.065 \\
\hline Enterprises - NRS & 1.377 & 1.735 & 1.055 \\
\hline \multicolumn{4}{|l|}{ Capital } \\
\hline Enterprises $-\mathrm{RS}$ & 1.395 & 1.795 & 1.105 \\
\hline Enterprises - NRS & 1.414 & 1.760 & 1.101 \\
\hline \multicolumn{4}{|l|}{ Net income } \\
\hline Enterprises $-\mathrm{RS}$ & 1.049 & 1.056 & 1.007 \\
\hline Enterprises - NRS & 1.059 & 1.107 & 1.006 \\
\hline \multicolumn{4}{|l|}{ Number of employees } \\
\hline Enterprises - RS & 1.061 & 1.087 & 1.021 \\
\hline Enterprises - NRS & 1.055 & 1.088 & 1.023 \\
\hline \multicolumn{4}{|c|}{ OROE (Operating revenues to operating expenses) } \\
\hline Enterprises - RS & 1.246 & 1.547 & 1.174 \\
\hline Enterprises - NRS & 1.056 & 1.597 & 0.814 \\
\hline \multicolumn{4}{|c|}{ VPE (Value added per employee) } \\
\hline Enterprises - RS & 1.356 & 1.662 & 1.063 \\
\hline Enterprises - NRS & 1.362 & 1.684 & 1.051 \\
\hline
\end{tabular}

Note: RS means enterprises received subsidies and NRS means enterprises did not received subsidies. 
terprises that received subsidies showed poorer growth in the period before receiving the subsidie and better growth than the enterprises that did not receive subsidies in the period after receiving the subsidies. The enterprises that received subsidies had more capital during both periods. Interestingly, the growth of employees was higher during both periods in the enterprises that did not receive subsidies.

\section{Discussion}

EU contributes funds for cohesive development of regions to its members. These funds are distributed through a number of programs and tenders, separated by area. One of such tenders was P4, in which subsidies were granted for investments in technological equipment, and which is analyzed in this paper. Tenders in the $\mathrm{P} 4$ program were published in the 2006-2009 period, when almost EUR 316 million was made available, with subsidies amounting to some EUR 135.3 million. This study focused on direct effects, i.e. on business and financial performance indicators and other effects, and impact on innovation. To test the $\mathrm{H} 1$ set, financial effects were measured using four business and financial performance indicators. In general, SMEs achieved positive financial impact from subsidies granted through $\mathrm{P} 4$. Based on the three analyzed financial indicators, SMEs that were successful in the $\mathrm{P} 4$ public tender perform better than the average of all enterprises operating in the eligible industries. Thus, the H1 set cannot be rejected. Well performing SMEs are more likely to have the capacity to efficiently apply and compete in the P4 public tender, which further increases their competitive edge and the level of business efficiency.

To test the $\mathrm{H} 2$ set, the multiple regression analysis was conducted using previously determined principal components as independent variables. In the H2 set, SMEs performance is measured through the impact of innovation. Value added per employee is significantly positively associated with the principal component Innovation as a prerequisite and to a lesser extent with the principal component Innovation and the way to innovate, but not with two other components. This means that the $\mathrm{H} 2$ set cannot be rejected only partly.

In the H3 set, we have established that the enterprises that received subsidies on average achieved higher growth of financial indicators than the enterprises that did not receive them. In addition, the enterprises that received subsidies had higher average scores for the statements in the social, ecological, and economic aspects of sustainable development.
In our case, $44.1 \%$ of SMEs that responded to the questionnaire have poorly developed innovation. For comparison, there is investigated the effect of subsidies in SMEs in Germany [48]. They found that SMEs that received grants directly from the EU are more innovative than SMEs that received grants through national institutions, as was P4. Micro enterprises do not usually apply to direct calls from the EU. A micro enterprise is defined as an enterprise with fewer than 10 employees, whose annual revenue and/or annual balance sheet total does not exceed EUR 2 million. Most of them do not qualify in tenders, because they are too small or do not have enough staff and/or capacities for research activities. They do not have operational capabilities required for implementing the project. Micro enterprises are more likely to generate the major part of their revenue through the production of well-known products for known customers. They do not usually have their own R\&D departments and are accordingly investing less in innovation activities. Most SMEs that received subsidies in $\mathrm{P} 4$ are classified under activities C: Manufacturing in the standard classification of activities (NACE). In general, the government subsidies distributed through P4 in Slovenia achieved their goal and had a positive impact on the SMEs' performance. The impact was greater on financial indicators than on innovation. This suggests that managers in Slovenian SMEs do not pay enough attention to innovation. For the majority of micro and even small enterprises, innovation still means upgrading subscriber documents or plans to the level of SME's technological equipment capacity. Only by boosting innovation and increasing the number of new innovative products could Slovenian SMEs raise the quality level of their products or services to the EU level, which is consistent with the declining or stagnating GCI for the Slovenian economy [49].

\section{Conclusion}

The novelty and contribution of this paper is that it assesses the impact that the subsidies distributed through the P4 public tender had on SMEs' business and financial performance, and innovation. This is the first study conducted in Slovenia measuring the impact of the specific P4 public tender on achieving the aims and objectives that were identified in the public tender designed to co-finance purchases of technological equipment in the 2006-2009 period. The results revealed that government subsidies have a more positive impact on SMEs' business and financial performance than on innovation. 
As subsidies are related to budgetary funds and taxpayers, it would be interesting to explore the impact of subsidies on financial performance and innovation for all tenders, not only the $\mathrm{P} 4$. Results are important not only for the purposes of research; they can have also important policy implications in relation to the implementation of government aid programs and EU directives.

\section{References}

[1] Council of the European Communities, Treaty on European Union. Office of Official Publications of the European Union, Brussels, 1992.

[2] Šipikal M., Pisár P., Labudová V., Are subsidies really needed? The case of EU regional policy in the Czech and Slovak Republics, E\&M Ekonomie a Management, 16, 4, 30-41, 2013.

[3] European Commission, Europe 2020, Strategy for smart, sustainable and inclusive growth, Brussels: European Commission, 2010.

[4] Commission of the European Communities, Think Small First. A Small Business Act for Europe, Brussels, 2008.

[5] Muller P., Devnani S., Julius J., Gagliardi D., Marzocchi C., Annual Report on European SMEs 2015/2016, Brussels: European Commission, 2016.

[6] Jenkins H., A critique of conventional CSR theory: an SME perspective, Journal of General Management, 29, 4, 37-57, 2004.

[7] Cunningham L., SMEs as motor of growth: a review of China's SMEs development in thirty years (19782008), Human System Management, 30, 1-2, 39-54, 2011.

[8] Mason C.M., Harrison R.T., After the exit: acquisitions, entrepreneurial recycling and regional economic development, Regional Studies, 40, 1, 55-73, 2006.

[9] Ayyagari M., Beck T., Demirguc-Kunt A., Small and medium enterprises across the globe, Small Business Economics, 29, 4, 415-434, 2007.

[10] Lin C., Success factors of small and medium-sized enterprises in Taiwan: an analysis of cases, Journal of Small Business Management, 36, 4, 43-56, 1998.

[11] Takalo T., Tanayama T., Adverse selection and financing of innovation: is there a need for R\&D subsidies?, The Journal of Technology Transfer, 35, 1, 16-41, 2010.

[12] Holger G., Strobl E., The Effect of RED Subsidies on Private R\&D, Economica, 74, 294, 215-234, 2007.
[13] Guidry R., Patten D., Market reactions to the firsttime issuance of corporate sustainability reports: evidence that quality matters, Sustainability Accounting, Management and Policy Journal, 1, 1, 33-50, 2010.

[14] Lozano R., Are companies planning their organisational changes for corporate sustainability? An analysis of three case studies on resistance to change and their strategies to overcome it, Corporate Social Responsibility and Environmental Management, 20, 5, 275-295, 2012.

[15] Hussinger K., R\&SD and subsidies at the firm level: an application of parametric and semiparametric two-step selection models, Journal of Applied Econometrics, 23, 6, 729-747, 2008.

[16] European Commission, EU Budget 2014, Luxemburg: Publications Office of the European Union, 2014.

[17] Bernini C., Pellegrini G., How are growth and productivity in private firms affected by public subsidy? Evidence from a regional policy, Regional Science and Urban Economics, 41, 1, 253-265, 2011.

[18] Government of the Republic of Slovenia, Single Programming Document 2004-2006, Ljubljana: Government of the Republic of Slovenia, 2003.

[19] Ministry of Economic Development and Technology, Slovenia's Development Strategy 2014-2020, draft, Slovenia: Ministry of Economic Development and Technology, 2013.

[20] European Commision, 2017, Financial framework 2007-2013, online: http://ec.europa.eu/budget/figures/fin_fwk0713/fwk0713_en.cfm\#cf07_13 (2.3.2017).

[21] Wallsten J.S., The effects of government-industry RED programs on private R\&D: the case of the small business innovation research program, The Rand Journal of Economics, 31, 1, 82-100, 2000.

[22] González X., Jaumandreu J., Pazó C., Barriers to innovation and subsidy effectiveness, The Rand Journal of Economics, 36, 4, 930-950, 2005.

[23] Czarnitzki D., Almus M., The effects of public RED subsidies on firms' innovation activities: the case of Eastern Germany, Journal of Business \& Economic Statistics, 21, 2, 226-236, 2003.

[24] Bojnec Š., Latruffe L., Farm size, agricultural subsidies and farm performance in Slovenia, Land Use Policy, 32, 207-217, 2013.

[25] Haase H., Franco M., What factors drive performance of small and medium - sized enterprises?, European Journal of International Management, 10, 6, 678-697, 2016. 
[26] Holger G., Henry M., Strobl E., Grant support and exporting activity, The Review of Economics and Statistics, 9, 1, 168-174, 2008.

[27] Bojnec Š., Fertő I., Impacts of research and development on manufacturing trade, Zbornik Radova Ekonomskog Fakulteta u Rijeci, 29, 1, 65-88, 2011.

[28] Bojnec Š., Fertő I., Research and development spending and export performance by the technological intensity of the products, Ekonomický časopis Journal of Economics, 62, 10, 1065-1080, 2014.

[29] Czarnitzki D., Ebersberger B., Fier A., The relationship between RED collaboration, subsidies and rESd performance: empirical evidence from Finland and Germany, Journal of Applied Econometrics, Special Edition: The Econometrics of Industrial Organization, 22, 7, 1347-1366, 2007.

[30] Arqué-Castells P., Persistence in RED performance and its implications for the granting of subsidies, Review of Industrial Organization, 43, 3, 193-220, 2013.

[31] Czarnitzki D., Toole A., Business R\&D and the interplay of RED subsidies and product market uncertainty, Review of Industrial Organization, 31, 3, 169-181, 2008.

[32] Bertoncelj A., Meško M., Naraločnik A., Nastav B., Sedmak G., Trajnostni razvoj organizacije: ekonomski, družbeno-politični in ekološki vidiki, Ljubljana: GV zaloz`ba, 2011.

[33] Zook C., Allen J., Profit from the core: growth strategy in an era of turbulence, Boston: Harvard Business School Press, 2001.

[34] Government Office for Development and European Cohesion Policy, Slovenian Smart Specialization Strategies, S4, Ljubljana: Government Office for Development and European Cohesion Policy, 2014.

[35] Engel K., Dirlea V., Dyer S., Graff J., How to build the permanently innovative company: five tested sets of management practices, Strategy \& Leadership, 43, 1, 3-10, 2015 .

[36] Venkatraman N., Ramanujam V., Measurement of business performance in strategy research: a comparison of approaches, The Academy of Management Review, 11, 4, 801-814, 1986.

[37] De Wall A., The secret of high performance organizations, Management online Review, ISSN 19963300, 2008.
[38] Bergström F., Capital subsidies and the performance of firm, Small Business Economics, 14, 3, 183-93, 2000 .

[39] Buigues P.A., Sekkat K., Public subsidies to business: an international comparison, Journal of Industry, Competition and Trade, 11, 1, 1-24, 2011.

[40] Koski H., Pajarinen M., Subsidies, the shadow of death and labor productivity, Journal of Industry, Competition and Trade, 15, 2, 189-204, 2015.

[41] Tzelepis D., Skuras D., The effects of regional capital subsidies on firm performance: an empirical study, Journal of Small Business and Enterprise Development, 11, 1, 121-129, 2004.

[42] Ajpes Slovenian Business Register, data base, 2013.

[43] Košmelj K., Principal components: basics and example, Acta Agriculturae Slovenica, 89, 1, 159-172, 2007.

[44] European Commission, Commission Staff Working Document. Country Report - Slovenia 2015, Brussels: European Commission, 2015.

[45] European Commission, Research and Innovation Performance in the EU. Innovation Union Progress at Country Level, Luxemburg: Publications Office of the European Union, 2014.

[46] Official Journal of the European Union (2013) Regulation (EU) No. 1301/2013 of the European Parliament and of the Council of 17 December 2013 on the European Regional Development Fund and on specific provisions concerning the Investment for growth and jobs goal and repealing Regulation (EC) No $1080 / 2006$. Official Journal of the European Union, $347 / 289$.

[47] Government Office for Development and European Cohesion Policy, National Strategic Reference Framework 2007-2013, Ljubljana: Government Office for Development and European Cohesion Policy, 2012 .

[48] Czarnitzki D., Lopes C. B., Innovation subsidies: Does the funding source matter for innovation intensity and performance? Empirical Evidence from Germany, Industry and Innovation, 21, 5, 380-409, 2014.

[49] Schwab K., The Global Competitiveness Report 2013-2014, Geneva: World Economic Forum, 2014. 